\title{
About Movement Disorders
}

\author{
Pellegrino Fernando Carlos* \\ Professor, Buenos Aires, Argentina
}

Submission: February 13, 2019; Published: February 20, 2019

*Corresponding author: Pellegrino Fernando Carlos, Professor, Buenos Aires, Portela 925 -Buenos Aires city, Argentina

\section{Opinion}

Twenty years ago, veterinary neurology was easier. If a dog fell with stiffness in his limbs and unconscious, he had a seizure; if his stiffness was limited to one part of his body, he had a focal seizure, which was attributed to structural brain damage. Although this statement may seem like an extreme simplification, it describes with enough certainty what happened not so long ago. Now we know that a variety of focal seizures (that sometimes do not look like seizures) are one of the phenotypic expressions of idiopathic epilepsy, and that there are numerous disorders which may mimic epileptic seizures. Among them are the movement disorders, described as involuntary movements (IM) and paroxysmal disorders [1]. They are a heterogeneous group of diseases in humans and animals characterized by involuntary movements without changes in consciousness [2]. Clinically, those can be focal or generalized and can last a second or several minutes to hours. Additionally, those may be intermittent, sustained, episodic or related to systemic disorders. Breed information and a good history, including the age of onset, character of movements, precipitating or alleviating factors, and associated signs are essential to rule in or out possible differential diagnosis [3]. The frequency of IM in dogs is undetermined, although this may largely be due to under-recognition [4]. But every day they are diagnosed more frequently.

In humans, the clinical presentation of movement disorders is complex, often variable, and sometimes even bizarre. Establishing the correct diagnosis can, therefore, be difficult, even in the hands of experienced movement disorder specialists [5]. The initial steps in the diagnosis of IM are to properly identify and classify them and to differentiate them from other conditions that can also affect movement, such as epileptic seizures and other nonepileptic paroxysmal disorders [6]. The investigational work-up can be greatly simplified once the type of IM has been identified, because the approach to each type of movement disorder then becomes more focused [7]. Although ancillary aids can provide confirmation for many movement disorders, or at least eliminate diseases that may mimic the condition, the initial diagnosis is based primarily on the observation of clinical signs. However, recognizing a movement disorder is not easy. A recent study highlighted the challenge in differentiating epileptic and non-epileptic paroxysmal events. This study investigated the level of agreement between veterinarians (both neurology specialists and non-specialists) in the description and classification of videos described canine and feline paroxysmal events, where the observers were blinded to the history, results of diagnostic investigations and treatment response [8]. The level of agreement on whether a paroxysmal event was an epileptic seizure or other paroxysm was relatively low, especially about motor signs. Undoubtedly, identifying the type of movement disorder is a clinical challenge that becomes more difficult when a patient presents more than one abnormal movement simultaneously as, for example, in paroxysmal dyskinesis [2,3,9].

Classification systems are necessary to provide a framework for the study of aetiology, pathogenesis, and treatment of IM, and to facilitate recognition and diagnosis [1,4]. In dogs, sustained involuntary skeletal muscle contraction leading to muscle stiffness can originate from the muscles (eg, myotonia) $[9,10]$, the peripheral nervous system (eg, myokymia, neuromyotonia, fasciculations or cramps -peripheral nerve hiperexcitability-) $[4,11,12]$, or the central nervous system (eg, tetanus, myoclonus, tremor, dystonia or movement disorders such as paroxysmal dyskinesis) $[4,5,13]$. The accurate recognition of the type of IM is critical for a correct approach to the diagnosis and allows an initial classification based on the neuroanatomical location (muscle, peripheral or central nervous system). The following subclassifications should consider whether the disorder is primary (hereditary or genetic) or acquired, and the extent of clinical signs (focal or generalized).

Finally, at the end of the road, all this information can guide us towards the underlying etiology. Some authors have made notable efforts to provide a classification system $[2,4,7,9,14]$ but, ultimately, these schemes can be overcomplicated in veterinary medicine when so few of these disorders are seen and definitively diagnosed [14]. As we learn more about the aetiology and pathogenesis of IMs, future revisions to the classification will be needed. IM exist in veterinary medicine, and we must begin to consider them in the differential diagnoses of paroxysmal events that affect movement. There are many articles that provide a detailed description of all types of IM $[3,4,7,9,12,15]$, but it is still 
necessary to establish a practical and operational classification system, performed by expert neurologists, and additional training of non-specialist veterinarians to facilitate accurate diagnosis.

\section{References}

1. Strain GM (2016) A framework for movement disorders in canine neurology. The Veterinary Journal 214: 122-123.

2. Urkasemsin G, Olby NJ (2014) Canine paroxysmal movement disorders. Vet Clin North Am Small Anim Pract 44: 1091-1102.

3. Prikryl M, Cherubini GB, Palus V (2018) Neurogenic hyperkinetic movement disorders in dogs. Companion Animal 23(4): 1-7.

4. Lowrie M, Garosi L (2016) Classification of involuntary movements in dogs: tremors and twitches. The Veterinary Journal 214: 109-116.

5. Abdo WF, van de Warrenburg BPC, Burn DJ, Quinn NP, Bloem BR (2016) The clinical approach to movement disorders. Nat Rev Neurol 6: 29-37.

6. Delgado MR, Albright AL (2003) Movement disorders in children: definitions, classifications, and grading systems. J Child Neurol 18: S1-S8.

7. Lowrie M, Garosi L (2017a) Classification of involuntary movements in dogs: paroxysmal dyskinesias. The Veterinary Journal 220: 65-71.

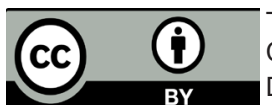

This work is licensed under Creative Commons Attribution 4.0 License

DOI: 10.19080/JDVS.2019.10.555781
8. Packer RMA, Berendt M, Bhatti S, Charalambous M, Cizinauskas S, et al. (2015) Inter-observer agreement of canine and feline paroxysmal event semiology and classification by veterinary neurology specialists and nonspecialists. BMC Vet Res 1: 39.

9. Lowrie M, Garosi L (2017b) Classification of involuntary movements in dogs: myoclonus and myotonia. J Vet Intern Med 31: 979-987.

10. Vite CH (2002) Myotonia and disorders of altered muscle cell membrane excitability. Vet Clin North Am Small Anim Pract 32: 169-187.

11. Shelton GD (2004) Muscle pain, cramps and hypertonicity. Vet Clin North Am Small Anim Pract 34: 1483-1496.

12. Vanhaesebrouck AE, Van Soens I, Poncelet L (2010) Clinical and electrophysiological characterization of myokymia and neuromyotonia in Jack Russell Terriers. J Vet Intern Med 24: 882-889.

13. de Lahunta A, Glass E (2009) Uncontrolled Involuntary Skeletal Muscle Contractions, ( $3^{\text {rd }}$ edn), Philadelphia, PA: Saunders; 206-220.

14. Dewey CW, da Costa RC (2016) Practical Guide to Canine and Feline Neurology, ( $3^{\text {rd }}$ edn), Wiley Blackwell, Ames, IA, USA.

15. Vanhaesebrouck AE, Bhatti SFM, Franklin RJM, Van Ham L (2013) Myokymia and neuromyotonia in veterinary medicine: a comparison with peripheral nerve hyperexcitability syndrome in humans. The Veterinary Journal 197: 153-162

\begin{tabular}{l} 
Your next submission with Juniper Publishers \\
will reach you the below assets \\
- Quality Editorial service \\
- Swift Peer Review \\
- Reprints availability \\
- E-prints Service \\
- Manuscript Podcast for convenient understanding \\
- Global attainment for your research \\
- Manuscript accessibility in different formats \\
( Pdf, E-pub, Full Text, Audio) \\
- Unceasing customer service \\
Track the below URL for one-step submission \\
https://juniperpublishers.com/online-submission.php \\
\hline
\end{tabular}

